\title{
Incidence of the retromolar foramen in dry mandibles and its significance for dental surgical procedures
}

\author{
Gislainy Thais de Lima Lemos ${ }^{1 *}$ \\ Anderson Alves da Silva Bezerra ${ }^{1}$ \\ Silvia Maria de Luna Alves ${ }^{1}$ \\ Sidiane Barros da Silva ${ }^{1}$ \\ Taciana Rocha dos Santos ${ }^{2}$ \\ Carolina Peixoto Magalhães ${ }^{1}$ \\ ${ }^{1}$ Universidade Federal de Pernambuco, Centro Acadêmico de Vitória \\ Rua Alto do Reservatório, s/n, Bela Vista, CEP 55.608-680, Vitória de Santo Antão - PE, Brasil \\ ${ }^{2}$ Universidade Federal do Piauí, Campus Senador Helvídio Nunes de Barros \\ Rua Cícero Duarte, 905 - Junco, CEP 64.607-670, Picos - Piauí, Brasil \\ * Correspondent author \\ gislainylemos@gmail.com
}

Submetido em 10/08/2019

Aceito para publicação em 14/12/2019

\section{Resumo}

Incidência do forame retromolar em mandíbulas secas e sua importância em procedimentos cirúrgicos odontológicos. O forame retromolar, assim como o canal retromolar, são variações anatômicas da mandíbula que se apresentam na região do trígono retromolar. Esse forame e canal contêm estruturas neurovasculares que fornecem inervação adicional aos molares inferiores e à área bucal. Objetivou-se verificar a incidência e ocorrência entre os sexos do forame retromolar em mandíbulas da Coleção de Ossos Contemporâneos da Universidade Federal de Pernambuco. Foram analisadas 61 mandíbulas secas, sendo 37 masculinas e 24 femininas. Das 61 mandíbulas, 18 apresentaram o forame retromolar $(29,5 \%)$, sendo 12 mandíbulas apresentando o forame unilateralmente $(19,67 \%)$. As mandíbulas masculinas apresentaram uma maior incidência comparada às femininas, tendo totalizado $12(32,43 \%)$ mandíbulas com forame retromandibular. A população analisada mostra uma alta incidência do forame retromolar, especialmente para o lado direito. A identificação dessa variação anatômica auxilia no planejamento de cirurgias e durante os procedimentos anestésicos.

Palavras-chave: Anestesia; Assistência odontológica; Nervo mandibular; Variação anatômica

\section{Abstract}

The retromolar foramen and retromolar canal as well are anatomical variations of the mandible that occur in the region of the retromolar trigone. This foramen and canal contain neurovascular structures that provide additional innervation to the lower molars and buccal area. This study aimed to determine the incidence and occurrence between the sexes of the retromolar foramen in mandibles of the Contemporary Bone Collection 
of the Federal University of Pernambuco. Sixty-one dry mandibles were analyzed, 37 from males and 24 from females. Of the 61 mandibles, 18 had retromolar foramina $(29.5 \%)$, and 12 had a unilateral foramen (19.67\%). Male mandibles had a higher incidence compared to female bones, with $12(32.43 \%)$ mandibles with retromandibular foramina. The population analyzed showed a high incidence of the retromolar foramen, especially on the right side. The identification of this anatomical variation helps in the planning of oral surgeries and during anesthetic procedures.

Key words: Anatomic variation; Anesthesia; Dental care; Mandibular nerve

\section{Introduction}

The retromolar foramen (RMF) and retromolar canal (RMC) as well are anatomical variations of the mandible that occur in the region of the retromolar trigone. The retromolar region is bordered by the anterior margin of the ramus of the mandible, temporal crest and distal aspect of the last lower molar. The RMC shows morphological and morphometric variations (KAWAI et al., 2012), including a posterior concavity (LANGLAIS et al., 1985), as well as straight RMC (PATIL et al., 2013).

Because of their presence being inconstant, most anatomy textbooks and atlases do not make reference to these structures (MOTTA-JÚNIOR et al., 2012). An arteriole, a venule and a myelinated nerve from the inferior alveolar nerve pass through these structures (BILECENOGLU; TUNCER, 2006). The RMF is derived from the exposure of the nerve bundle that originates from the branch of the third division of the trigeminal nerve and passes through the RMC, which goes posteriorly to the third molar region (ANDERSON et al., 1991). The study of this foramen is important for the planning of oral surgical procedures, such as in the reconstruction of the mandible. The lack of knowledge about the presence of these structures can lead to failures in the anesthesia process, such as paresthesia or paralysis (CAPOTE et al., 2015). Even though they are described in the literature (ROSSI et al., 2012; POTU et al., 2014), few health care providers, especially dentists, have knowledge about these anatomical structures. Therefore, the study of the incidence of RMF and RMC is important in a surgical anatomical context. Our aim was to study a university bone collection and to determine the incidence of the RMF and frequency of its unilateral or bilateral occurrence and correlations with sex.

\section{Materials and Methods}

For this study, 61 dry and completely ossified mandibles from the Contemporary Bone Collection of the Federal University of Pernambuco were used. Of the total 61 mandibles, 24 were from females and 37 from males. They were analyzed by two of the authors according to Rossi et al. (2012), and the concordances between the examiners were then observed. The presence or absence of the RMF was recorded (Figure 1), and the occurrence between the sexes was determined. In addition, we determined the unilateral and bilateral frequency of the RMF, and its unilateral incidence between the right and left side of the mandible. All data were described as absolute and relative values. Exclusion criteria for this study were evidence of trauma, wear, damage or any pathological alteration, and bone age less than 18 years. The present study was approved and authorized by the Ethics Committee on Research of the Federal University of Pernambuco, CAAE no 66287517.7.0000.5208. 
FIGURE 1: Top left view of a mandible with presence of retromolar foramen.

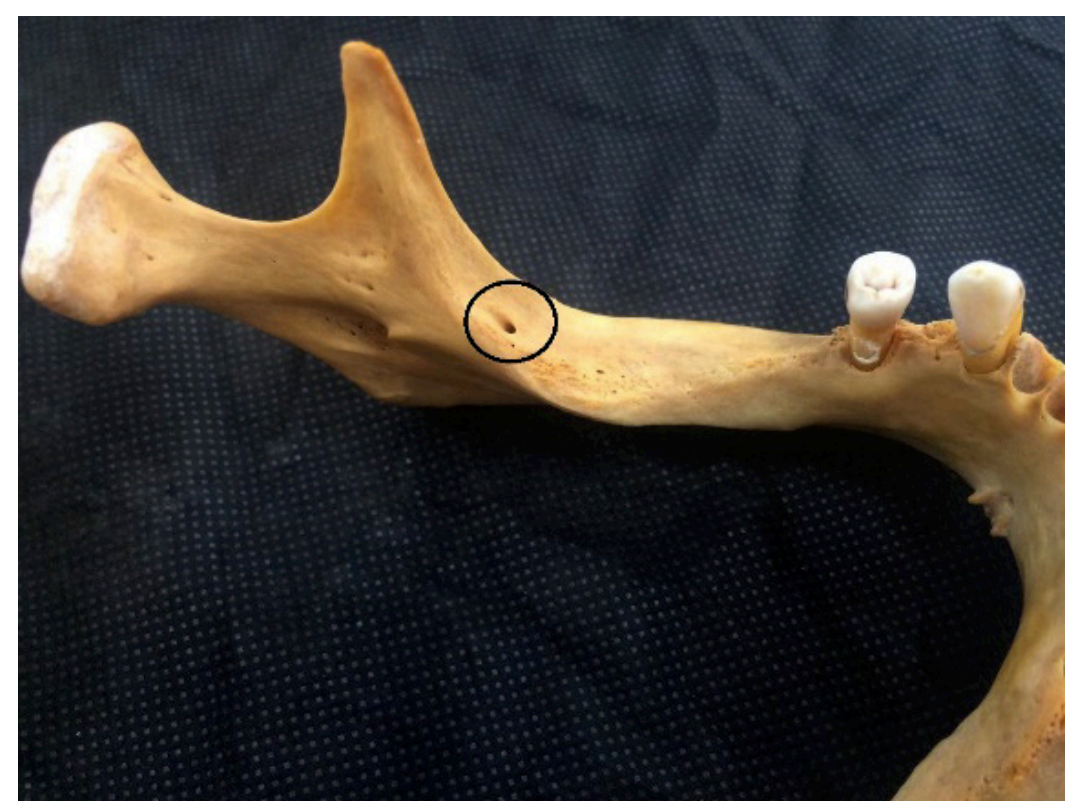

\section{Results and Discussion}

It was observed that of the 61 mandibles examined, 18 showed the RMF, corresponding to $29.5 \%$ (Table 1). This percentage is close to that reported by Rossi et al. (2012), who found the RMF in $26.58 \%$ of 222 mandibles analyzed. Ossenberg (1986) believes that the high foramen incidence in the Brazilian population is related to heterogeneity of the people.

TABLE 1: Absolute (n) and relative (\%) incidence rates of retromolar foramen according to sex

\begin{tabular}{ccccccc}
\hline & \multicolumn{2}{c}{ Female } & \multicolumn{2}{c}{ Male } & \multicolumn{2}{c}{ Total } \\
\cline { 2 - 7 } & $\mathbf{n}$ & $\mathbf{\%}$ & $\mathbf{n}$ & $\mathbf{\%}$ & $\mathbf{n}$ & $\mathbf{\%}$ \\
\hline Presence & 06 & 25 & 12 & 32.44 & 18 & 29.51 \\
Absent & 18 & 75 & 25 & 67.56 & 43 & 70.49 \\
\hline Total & 24 & 100 & 37 & 100 & 61 & 100 \\
\hline
\end{tabular}

Freitas et al. (2017) detected a 5.0\% prevalence of RMCs. Several other studies have evaluated the presence of RMCs, reporting a wide variation in prevalence depending on the method used (SANTOS et al., 2013). According to Freitas et al. (2017), an additional RMF had a prevalence of $7.33 \%$ in the population studied. Bilecenoglu and Tuncer (2006) reported a prevalence of
$25 \%$ for histologically demonstrated RMFs and that the canals had myelin nerve fibers, an artery and numerous venules, providing for part of the third molar, as well as the retromolar mucosa.

The frequency of this anatomical variation in certain population groups should be taken into account during maxillo-axial procedures, since the retromolar trigone region is subjected the most to oral surgeries (BATAINEH et al., 2002; HUANG; RUE, 2006; FRIEDMAN, 2007; WOLDENBERG et al., 2007).

Because it is a vascularized and innervated site, the presence of RMF implies difficulties in blocking the local nerve endings, as well as possible ruptures of vessels and nerves, leading to paresthesia, hemorrhage and even paralysis (KAWAI et al., 2012). The retromolar trigone region is also a favorable site for the appearance of malignant tumors and the probability of carcinomas that may spread along the pterygomandibular fossa towards the infratemporal fossa, causing severe complications in an individual's health (SOUZA et al., 2003).

Our finding was superior to that reported by Potu et al. (2014), who analyzed 94 mandibles of the Indian population and found RMFs in $11.7 \%$. This 
divergence of results may be associated with the ethnic differences of the populations evaluated. Previous studies have found a variation in the incidence of the foramen of 3.2 to $75.4 \%$ among different populations (OSSENBERG, 1986; MOTTA-JUNIOR et al., 2012; LIZIO et al., 2013).

Ossenberg (1986) highlights this difference between populations when analyzing the percentage of RNF between different groups, such as Italy $8.1 \%$, Japan 3.2\%; Eskimos 8.2\%, and Canadians of European descent $9.1 \%$. However, the study by Alves and Deana (2015) disagrees with this notion and reports that there are variations in the incidence of RMF in the same ethnic group.

We also found a higher incidence of this foramen in male mandibles, where RMF occurred in $12(32.43 \%)$ of 37 mandibles. In contrast, female bones showed the RMF in $6(24 \%)$ of 24 mandibles (Table 1). Han and Hwang (2014) affirm that there are no differences between the sexes, which did not agree with our results.

Previous studies have found that the presence of RMF is commonly unilateral (PRIYA et al., 2005; BILECENOGLU; TUNCER, 2006; ROSSI et al., 2012; LIZIO et al., 2013; HAN; HWANG, 2014). In concordance, our study evidenced the unilateral presence of RMF in $12(19.67 \%)$ mandibles and bilateral in 6 $(9.83 \%)$ (Table 2). Regarding the presence of RMF on the right or left side, it was greater on the right side with $9(14.75 \%)$ mandibles, compared to the left side with 3 (4.91\%) mandibles (Table 2). Han and Hwang (2014) and Narayana et al. (2002) also observed a higher incidence on the right side. On the other hand, Priya et al. (2005) and Motta-Junior et al. (2012) reported a higher frequency on the left side.

TABLE 2: Absolute (n) and relative (\%) frequencies of retromolar foramen according to location.

\begin{tabular}{cccccc} 
& $\mathbf{n}$ & $\mathbf{\%}$ & & $\mathbf{n}$ & $\mathbf{\%}$ \\
\hline Unilateral & 12 & 19.67 & Right & 9 & 14.75 \\
\cline { 3 - 6 } & & & Left & 3 & 4.91 \\
\hline Bilateral & 6 & 9.84 & & & \\
\hline Absent & 43 & 70.49 & & & \\
\hline Total & 61 & 100 & & & \\
\hline
\end{tabular}

Therefore, the sample analyzed showed a high incidence of RMF in the mandibles analyzed, and mainly on the right side. In relation to the sexes, the male mandibles had a greater frequency of this foramen. This may result in a high risk of bleeding, paraesthesia or paralysis during dental surgical procedures. Therefore, the study of this anatomical variation is extremely important for dentists and oral surgeons, since they must be aware of the risks and complications during anesthetic and surgical procedures.

\section{Acknowledgements}

The authors would like to thank the Anatomy Laboratory of the Academic Center of Vitoria/UFPE and all the team involved in the LAECAV project.

\section{References}

ALVES, N.; DEANA, N. Estudo anatômico e radiográfico do canal retromolar e forame retromolar em mandíbulas maceradas. International Journal of Clinical and Experimental Medicine, Augusta, v. 8, n. 3, p. 4292-4296, 2015.

ANDERSON, L. C.; KOSINSKI, T. F.; MENTAG, P. J. A review of the intraosseous course of the nerves of the mandible. International Journal of Oral Implantology, Berlin, v. 17, n. 4, p. 394-403, 1991.

BATAINEH, A. B.; ALBASHAIREH, Z. S.; HAZZA'A, A. M. The surgical removal of mandibular third molars: a study in decision making. Quintessence International, Berlin, v. 33, n. 8, p. 613$617,2002$.

BILECENOGLU, B.; TUNCER, N. Clinical and anatomical study of retromolar foramen and canal. Journal of Oral and Maxillofacial Surgery, Rosemont, v. 64, n. 10, p. 1493-1497, 2006.

CAPOTE, T. S. O.; GONÇALVES, M. A.; CAMPOS, J. A. D. B. Retromolar canal associated with age, side, sex, bifid mandibular canal, and accessory mental foramen in panoramic radiographs of Brazilians. Anatomy Research International, London, v. 2015, p. $1-8,2015$.

FRIEDMAN, J. W. The prophylactic extraction of third molars: a public health hazard. American Journal of Public Health, Boston, v. 97, n. 9, p. 1554-1559, 2007.

FREITAS, G. B. de; FREITAS E SILVA, A.; MANHÃES JÚNIOR, L. R. C. The prevalence of mandibular retromolar canals on cone beam computed tomography and its clinical repercussions. Revista de Odontologia da UNESP, São Paulo, v. 46, p. 3, p. 158-163, 2017.

HAN, S. S.; HWANG, Y. S. Achados de tomografia por feixe cônico de canais retromolares em uma população coreana. Surgical and 
Radiologic Anatomy, Heidelberg, v. 36, p. 871-876, 2014.

HUANG, G. J.; RUE, T. C. Third-molar extraction as a risk factor for temporomandibular disorder. The Journal of the American Dental Association, Buffalo, v. 137, n. 11, p. 1547-1554, 2006.

KAWAI, T.; ASAUMI, R.; SATO, I.; KUMAZAWA, Y. de; YOSUE, T. Observation of the retromolar foramen and canal of the mandible: a CBCT and macroscopic study. Oral Radiology, Okayama, v. 28, n. 1, p. 10-14, 2012.

LANGLAIS, R. P.; BROADUS, R.; GLASS, B. J. Bifid mandibular canals in panoramic radiographs. Journal of the American Dental Association, Chicago, v. 110, n. 6, p. 923-926, 1985.

LIZIO, G.; PELLICCIONI, G. A.; GHI, G.; FANELLI, A.; MARCHETTI, C. Radiographic assessment of the mandibular retromolar canal using cone-beam computed tomography. Acta Odontologica Scandinavica, Copenhagen, v. 71, n. 3-4, p. 650655,2013

MOTTA-JUNIOR, J.; FERREIRA, M. L.; MATHEUS, R. A; STABILE, G. A. V. Forame retromolar: sua repercussão clínica e avaliação de 35 mandíbulas secas. Revista de Odontologia da UNESP, Araraquara, v. 41, p. 164-168, 2012.

NARAYANA, K.; NAYAK, U. A.; AHMED, W. N.; BHAT, J. G.; DEVAIAH, B. A. The retromolar foramen and canal in south Indian dry mandibles. European Journal of Anatomy, Salamanca, v. 6, p. 141-146, 2002.

OSSENBERG, N. S. Temporal crest canal: case report and statistics on a rare mandibular variant. Oral Surgery, Oral Medicine, Oral Pathology, and Oral Radiology, New York, v. 62, n. 1, p. 10-12, 1986.
PATIL, S.; MATSUDA, Y.; NAKAJIMA, K.; ARAKI, K.; OKANO, T. Retromolar canals as observed on cone-beam computed tomography: their incidence, course, and characteristics. Oral Surgery, Oral Medicine, Oral Pathology, Oral Radiology. Chicago, v. 115, n. 5, p. 692-699, 2013.

POTU, B. K.; KUMAR, V.; SALEM, A-H.; ABU-HIJLEH, M. Occurrence of the retromolar foramen in dry mandibles of southeastern part of India: a morphological study with review of the literature. Anatomy Research International, London, v. 2014, p. 1-5, 2014.

PRIYA, R.; MANJUNATH, K. Y.; BALASUBRAMANY, A. M. Forame retromolar. Indian Journal of Dental Research, New Delhi, v. 16, n. 1 p. 15-16, 2005.

ROSSI, A. C.; FREIRE, A. R.; PRADO, B. G.; PRADO, F. B.; BOTACIN, P. R.; CARIA, P. H. F. Incidence of retromolar foramen in human mandibles: ethnic and clinical aspects. International Journal of Morphology, Temuco, v. 30, n. 3, p. 1074-1078, 2012. SANTOS, O. JR.; PINHEIRO, L. R; UMETSUBO, O. S; SALES, M. A; CAVALCANTI, M. G. Assessment of open source software for CBCT in detecting additional mental foramina. Brazilian Oral Research, São Paulo, v. 27, n. 2, p. 128-35, 2013.

SOUZA, R. P.; PAGOTTO, S. R.; PAES JUNIOR, A. J. de O.; SOARES, A. H.; RAPOPORT, A. Diagnóstico por imagem da cavidade oral. Radiologia Brasileira, São Paulo, v. 36, n. 3, p. 169-172, 2003.

WOLDENBERG, Y.; GATOT, I.; BODNER, L. Iatrogenic mandibular fracture associated with third molar removal. Can it be prevented? Medicina Oral Patologia Oral y Cirugia Bucal, Valência, v. 12, n. 1, p. 70-72, 2007. 